\title{
Purine nucleoside phosphorylase deficiency associated with a fatal lymphoproliferative disorder
}

\author{
A R WATSON, D I K EVANS, H B MARSDEN, V MILlER, AND P A ROGERS \\ Booth Hall Children's Hospital, Manchester, and MRC Human Biochemical Genetics Unit, \\ The Galton Laboratory, University College, London
}

SUMMARY A $2 \frac{1}{2}$-year-old boy presented with an illness resembling glandular fever. He was found to have T-cell deficiency with lack of red and white cell purine nucleoside phosphorylase enzyme activity. A spastic tetraparesis was noted. The patient subsequently died of a malignant lymphoma of the B-immunoblastic type.

During the last 8 years two types of inborn defects of immunity, each of which has a genetically-determined biochemical basis, have been elucidated. ${ }^{1}$ Purine nucleoside phosphorylase (PNP) and adenosine deaminase (ADA) are enzymes in the purine salvage pathway. PNP catalyses the reversible conversion of inosine into hypoxanthine, of guanosine into guanine, and of xanthosine into xanthine. Lack of ADA is associated with severe combined immunodeficiency; but lack of PNP appears to cause a variable and progressive degree of predominantly $\mathrm{T}$ - but also B-lymphocyte dysfunction.

\section{Case report}

The patient* was a boy born by forceps delivery at term weighing $4 \cdot 1 \mathrm{~kg}$ to healthy parents who are 4th-cousins. There were no neonatal problems, but urinary tract infection was diagnosed at age 3 months. Right vesico-ureteric reflux was found at cystography and he was started on long-term suppressive antibiotic treatment. $\mathrm{He}$ had aseptic meningitis at age 2 years from which he made a normal recovery. By this time developmental delay had been noted with the inability to walk unsupported, a crude hand grasp, and delayed speech. Routine immunisation against diphtheria, tetanus, pertussis, and poliomyelitis had been performed.

He presented at age 2.8 years to our unit with a 3-week history of intermittent vomiting, fever, and dry cough. Examination showed an ill child with pronounced tonsillar exudate, cervical lymphadenopathy, oral moniliasis, and spastic tetraparesis. *MRC 4349

Initial investigations showed an $\mathrm{Hb}$ of $10 \mathrm{~g} / \mathrm{dl}$, platelets $275 \times 10^{9} / 1$, total white cell count $1.4 \times 10^{9} / 1$ with $50 \%$ neutrophils, $36 \%$ lymphocytes, $7 \%$ monocytes, $3 \%$ eosinophils, and $4 \%$ atypical monocytes. A positive monospot test appeared to confirm the initial clinical diagnosis of infectious mononucleosis.

The child remained ill and toxic for the next 2 weeks with increasing hepatosplenomegaly and a persistently low white cell count of betweeen 1 and $4 \times 10^{9} / 1$ with 4 to $16 \%$ atypical monocytes. Bone marrow examination showed a maturation arrest at the myelocyte/metamyelocyte stage with a reduced number of lymphocytes and no excess of blast cells. A full Paul-Bunnell test was negative and no antibodies to Epstein-Barr virus were detected. Antibodies to cytomegalovirus and toxoplasmosis were also not detectable. The peripheral blood Tlymphocyte count by the E-rosetting technique was only $1 \%$ (normal $50-75 \%$ ) with $11 \%$ B-cells (normal $5-15 \%$ ) identified by the surface immunoglobin.

The total serum protein was $67 \mathrm{~g} / 1$ with albumin $16 \mathrm{~g} / \mathrm{l}, \mathrm{IgG} 10.6 \mathrm{~g} / \mathrm{l}, \mathrm{IgA} 0.9 \mathrm{~g} / \mathrm{l}$, and a large increase in IgM levels at $8.5 \mathrm{~g} / \mathrm{l}$. The patient's blood group was $\mathbf{A}$ rhesus-positive, anti-B isohaemagglutinins were weakly detected only in neat serum, and poliovirus antibodies were present to a titre of $1 / 80$.

$\mathrm{He}$ was treated with prednisolone $30 \mathrm{mg} /$ day with no improvement in his condition. Vincristine $(0 \cdot 65$ $\mathrm{mg}$ ) was administered shortly before death when a cervical gland biopsy suggested malignant histocytic lymphoma.

No PNP activity was detectable in his red or white blood cells assayed a week before death by the method of Hopkinson et al. ${ }^{2}$ The levels of other enzymes, including ADA, were normal. The levels of PNP in several family members (Figure, further data to be published elsewhere) and the parental consanguinity confirm the autosomal recessive inheritance of PNP deficiency. A second boy was born in June 1980. He is currently healthy but he also lacks PNP. Chromosome analysis of the proband showed a normal XY karyotype with no abnormality of chromosome 14 to which the PNP gene has been localised. ${ }^{3}$ 


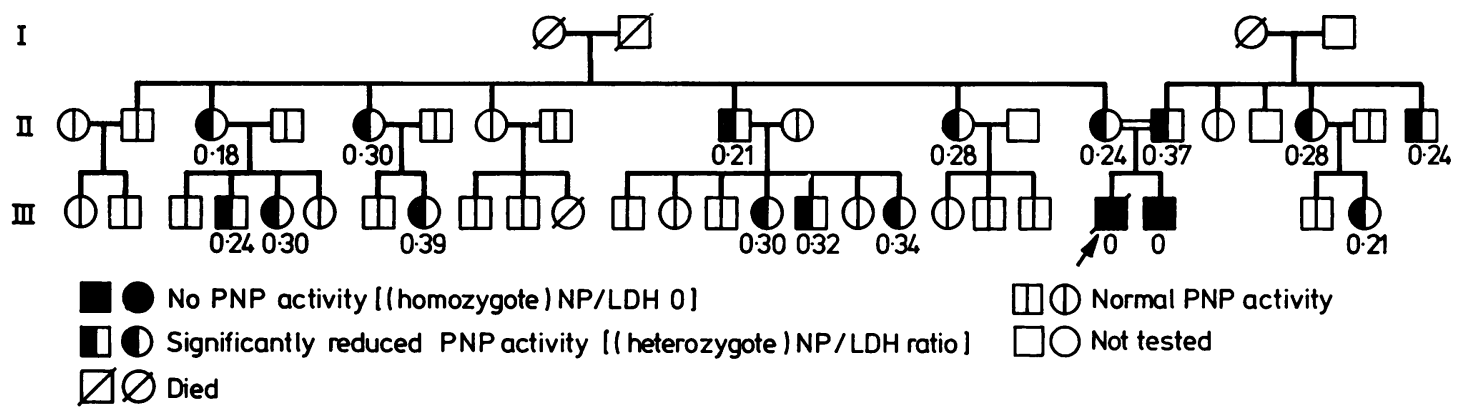

$$
\mathrm{NP} / \mathrm{LDH} \text { ratio }=\frac{\text { Purine nucleoside phosphorylase }}{\text { Lactate dehydrogenase }} \quad \begin{aligned}
& \text { units } / \mathrm{gHb} \\
& \text { units } / \mathrm{gHb}
\end{aligned} \quad \text { Normal adult } 0.69
$$

Figure Family of patient.

\section{Necropsy}

Gross examination showed massive hepatosplenomegaly, lymphadenopathy, and a very atrophic thymus. Histological studies showed dysplastic changes in the thymus with lymphocyte depletion, epithelial immaturity, absence of well-formed Hassall's corpuscles, and lack of cortical and medullary differentiation. There was lymphomatous infiltration of lymph nodes, thymus, liver, spleen, bone marrow, and lung. The cytoplasm of the tumour cells stained positively with pyronin (indicating RNA production) and this together with the ultrastructural features supported the diagnosis of malignant lymphoma of the B-immunoblastic type. No viral inclusions were seen.

\section{Discussion}

Analysis of the immunological results from the few families described with PNP deficiency would suggest depressed T-cell numbers and function from an early age, with only a mild B-cell dysfunction. ${ }^{1}$ Death in infancy is not as common as in ADA deficiency. It is suggested that the immune defect is due to selective accumulation in lymphoid tissues of toxic deoxyribonucleotides as a result of the enzyme deficiency. ${ }^{4}$ There is only one previous reference to a fatal lymphosarcoma occurring in a 3-year-old child with PNP deficiency. ${ }^{5}$ However, one should not be surprised to encounter further reports, as patients with T-cell or combined immunodeficiency states are at an appreciably greater risk of developing malignant lymphomas which are often of a B-immunoblastic type as in our patient. ${ }^{6}$ This case clearly shows a profound T-cell deficiency. Although the percentage of B-cells was normal, there was an absolute lymphopenia with consequently a low total circulating B-cell population. This and the low anti-B isohaemagglutinin titre also suggests a partial B-cell defect.
It is interesting that the child was initially thought to have infectious mononucleosis, as the Epstein-Barr virus is well known as a cell-transforming agent. Fatal cases of infectious mononucleosis have been associated with genetically-determined combined immunodeficiency states. ${ }^{7}$ However, in this case no Epstein-Barr virus antibodies could be detected and there was no evidence of viral infection by light or electron microscopical examination.

The spastic tetraparesis noted in our patient has been reported in one other family with PNP deficiency. ${ }^{8}$ The cause is unknown but the association may not be fortuitous. There is one other anomaly of purine metabolism associated with a profound neurological disturbance-that is hypoxanthineguanine phosphoribosyltransferase deficiency (LeschNyhan syndrome) where the metabolic block is only one step removed from that in PNP deficiency.

Recognition of other families with PNP deficiency will identify the immune defect still further and give greater insight into immunodeficiency states associated with malignancy.

\section{References}

1 Meuwissen H J, Parker K, Cook B. Inborn errors of specific immunity: adenosine deaminase deficiency and purine nucleoside phosphorylase deficiency. In: Güttler F, Seakins J W T, Harkness R A, eds. Inborn errors of immunity and phagocytosis. Lancaster: MTP Press, 1979:89.

${ }^{2}$ Hopkinson D A, Cook P J L, Harris H. Further data on the adenosine deaminase (ADA) polymorphism and a report of a new phenotype. Ann Hum Genet 1969; 32: 361-7.

3 Dallapiccola B, Magnani M, Dacha M, Giorgi P L. Letter: Confirmation of regional assignment of nucleoside phosphorylase to band $14 \mathrm{q} 13$ by gene dosage studies. Hum Genet 1979; 50: 341-3.

4 Carson D A, Kaye J, Seegmiller J E. Pathogenetic mechanisms in deficiencies of adenosine deaminase and purine nucleoside phosphorylase. In: Güttler F, Seakins J W T, Harkness R A, eds. Inborn errors of immunity and phagocytosis. Lancaster: MTP Press, 1979: 129. 
5 Stoop J W, Eijsvoogel V P, Zegers B J M, et al. Selective severe cellular immunodeficiency: effect of thymus transplantation and transfer factor administration. Clin Immunol Immunopathol 1976; 6: 289-98.

6 Spector B D, Perry G S, Good R A, Kersey J H. Immunodeficiency diseases and malignancy. In: Twomey $\mathrm{J} J$, Good R A, eds. The immunopathology of lymphoreticular neoplasms. London: Plenum, 1978: 203-22.

$?$ Purtilo D T, Szymanski I, Bhawan J, et al. Epstein-Barr virus infections in the $\mathrm{X}$-linked recessive lymphoproliferative syndrome. Lancet 1978; i: 798-801.
8 Stoop J W, Zegers B J M, Hendrickx G F M, et al. Purine nucleoside phosphorylase deficiency associated with selective cellular immunodeficiency. $N$ Engl J Med 1977; 296: 651-5.

Correspondence to Dr Alan R Watson, Department of Child Health, Royal Manchester Children's Hospital, Pendlebury, Manchester M27 1HA.

Received 11 August 1980

\title{
Transient neonatal hyperparathyroidism secondary to maternal pseudohypoparathyroidism
}

\author{
E J GLASS AND D G D BARR \\ Department of Child Life and Health, University of Edinburgh, and Simpson Memorial Maternity Pavilion, \\ Edinburgh
}

SUMMARY A neonate was found to have normocalcaemic hyperparathyroidism with bone disease. The plasma parathyroid hormone concentration returned to normal by 4 weeks, and healing of the bone lesions was evident by age 5 months. The mother proved to have pseudohypoparathyroidism, previously unsuspected.

Several cases of transient neonatal hyperparathyroidism secondary to untreated maternal hypoparathyroidism during pregnancy have been reported. ${ }^{1-6}$ An association between maternal pseudohypoparathyroidism and hyperparathyroidism in the fetus and newborn infant has not previously been recorded.
We describe an infant with transient neonatal hyperparathyroidism and severe skeletal changes radiologically. The mother was subsequently shown to have pseudohypoparathyroidism.

\section{Case report}

A girl was delivered by elective lower-segment caesarean section for breech presentation at term to a primigravid mother. Birthweight was $2.8 \mathrm{~kg}$. On initial examination bowing of both femora was noted and the hips were thought to be unstable. $X$-ray films showed extensive bony changes (Fig. 1a). Gross demineralisation of the skeleton was evident. Metaphyseal fractures of humeri, femora, and tibiae were present in addition to multiple rib fractures.

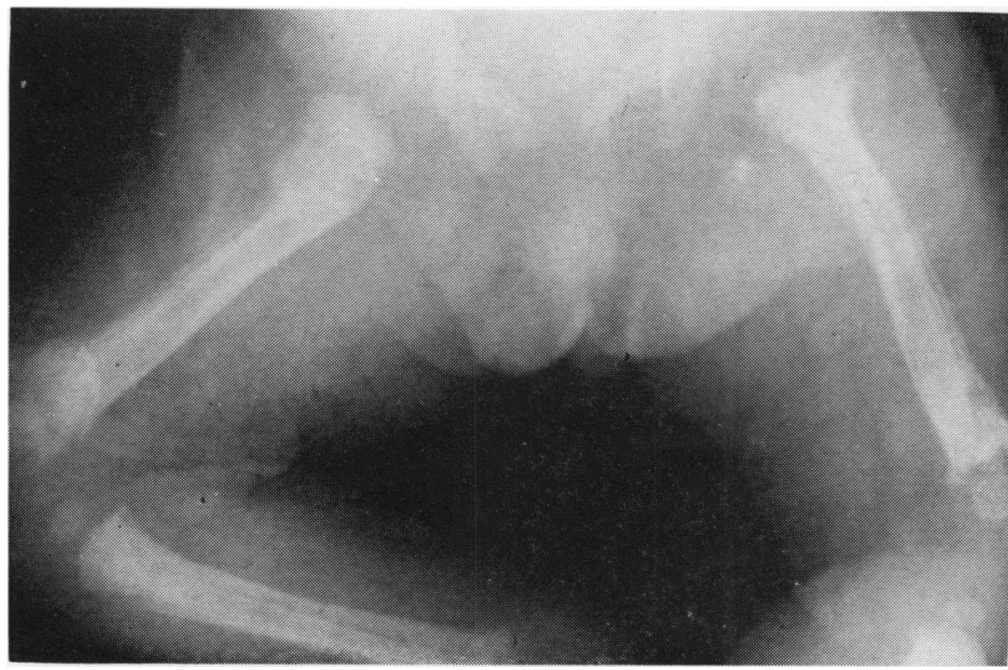

Fig. 1a Changes of hyperparathyroidism at age 1 week. $X$-ray film of femora, showing demineralisation of cortex, periosteal reactions along both shafts, and multiple metaphyseal fractures. 